\title{
The Effect of Transaction Experience Using Digital Wallets on User Satisfaction in Millennial Generation
}

\author{
Suryari Purnama1, Cicilia Sriliasta Bangun ${ }^{2}$, Safiani A. Faaroek ${ }^{3}$ \\ ${ }^{123}$ Universitas Esa Unggul, Jl. Arjuna Utara No 9, Jakarta, Indonesia \\ e-mail: suryari.purnama@esaunggul.ac.id, \\ cicilia.bangun@esaunggul.ac.id, annie.faaroek@esaunggul.ac.id
}

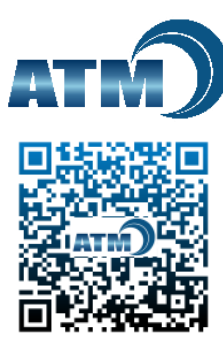

Author Notification 13 April 2021 Final Revised 18 April 2021 Published 15 July 2021

To cite this document :

Purnama, S., Bangun, C., \& Faaroek, A. (2021). The Effect of Transaction Experience Using Digital Wallets on User Satisfaction in Millennial Generation. Aptisi Transactions on Management (ATM), 5(2), 161-168.

DOI :

https://doi.org/10.33050/atm.v5i2.1593

\section{Abstract}

The purpose of this study to determine the effect after transaction failure and after failure recovery on the transaction experience, the effect after transaction failure and recovery from transaction failure using digital wallets on user satisfaction, especially in the millennial generation. The population of this study is all digital wallet users in the DKI Jakarta province with a total sample of 94 digital wallet users. The sampling method uses purposive sampling with the criteria of digital wallet users who have made transactions for at least 1 year, this is intended so that these respondents already have transaction experience and are at least 17 years old. Meanwhile, the data processing used Structural Equation Modeling analysis software Lisrel. The results showed: (1) Transaction failure affects the transaction experience of digital wallet users; (2) Transaction failure recovery will affect the transaction experience of digital wallet users; (3) Transaction experience affects the satisfaction of digital wallet users; (4) Transaction failure has no effect on digital wallet user satisfaction; (5) Transaction failure recovery affects the satisfaction of digital wallet users. The novelty of this research is transaction failure has no effect on digital wallet user satisfaction. In addition, the benefits that are felt are far greater than the failures that are experienced, especially when recovery from failure is carried out quickly and precisely.

Keywords: Service failure, Online Transaction Experience, Service Restoration, Satisfaction

\section{Introduction}

In today's society, the need to use digital wallets is quite high, especially the millennial generation. In this case, the type of retail transaction that is very often used by people who use electronic money in digital wallets. In addition, users also take advantage of online transportation orders (27 percent) and online food ordering (20 percent). The rest, for e-commerce transactions (15 percent) and bill payments (7 percent). It was also revealed that the results of research by 58 percent of respondents used the OVO brand as their favorite digital payment application. Other application-based digital wallets, such as Go-Pay (23 percent), DANA (6 percent), and LinkAja (1 percent), are considered by consumers to be merely a means of financing. The data shows that electronic money for daily transactions such as fast food delivery, transportation and shopping is increasingly popular among Indonesian consumers [1]. Consumers enjoy a more practical, fast, safe, and hassle-free transaction experience waiting for change.

In the online transportation ordering and online food delivery transaction segments, Snapcart's research data shows that the position of the OVO digital wallet as a Grab service (for online transportation) and GrabFood (for online food delivery), shows that 71 percent of respondents use OVO for this transaction segment, while 29 percent of respondents choose to use GoPay for transactions at Gojek and GoFood. Snapcart research data shows 70 percent of respondents use OVO for e-commerce transaction payments, while 11 percent use DANA, and 18 percent use GoPay. OVO is accepted in e-commerce, such as Tokopedia, Ruparupa and 
Sociolla, and GoPay is accepted, among others, at JD.id and Sayurbox, while DANA can be used at Bukalapak. Not only online retail and service transactions, digital payment application users often make transactions on various routine billing accounts, such as taxes, electricity, water, insurance and so on [2]. The use of electronic money makes paying various bills easier, safer and faster. Research data shows 67 percent of respondents use OVO based on this transaction segment, followed by GoPay (22 percent), DANA (10 percent), and LinkAja (2 percent).

A big influence on the survival of the company is the need to create customer satisfaction with digital wallets as a payment service provider [3]. Without customer satisfaction with services in the form of goods or services, the expectations of a company to grow and develop will be very difficult to achieve [4]. Today's consumers have better education, knowledge and information, they have various ways and facilities that make it easier for them to verify claims for service providers as well as to find alternative services that are better than before [5]. Quality and customer satisfaction have a very crucial role for a company to be successful and survive [6]. Quality and customer satisfaction are closely related to market share and customer retention. Increasing customer retention implies a greater distribution of positive information by word of mouth, decreasing price sensitivity, which in turn results in better business performance [7].

Based on this explanation, the aim of the research is to find out how the experience of transacting using a digital wallet on user satisfaction, especially among the millennial generation [8][9].

\subsection{Literature Review Service Failure}

Service failure is a significant determinant based on perceived customer dissatisfaction [10]. Service failures arise when customers experience perceived service dissatisfaction. It is important to remember, service failure is determined by the customer and not by the service organization [11]. Service failure can be defined as the customer's perception of one particular aspect, in this case the use of the service is not fulfilling the perceived expectations. When experiencing a service failure, there are many choices of actions that the customer may take. Furthermore, the measurement of service failure can be seen based on the user's perception of the difference between the predictions that users have of the performance of the digital wallet on the performance of the product or service after using the product or service when the condition has occurred transaction failure [12].

\section{Online Transaction Experience}

Customer experience as a subjective and internal response when the company interacts either directly or indirectly [13]. That future behavior is determined by previous experiences. Therefore, previous experience has a major influence on the buyer's decision to transact online [14]. Furthermore, the measurement of the online transaction experience takes into account important considerations from consumer perceptions when shopping based on their expectations of vendor services.

\section{Service Restoration}

Service recovery is an integrative action that companies need to rebuild customer satisfaction and loyalty after a service failure occurs and it can be ascertained that service failure will drive the recovery process in handling complaints [15]. Service restoration is not limited to customers who express their dissatisfaction [16]. Furthermore, the purpose of service recovery is to repair service failures characterized by customer complaints [17]. Meanwhile, to measure service recovery, it is seen based on users' perceptions of the recovery performance carried out by vendors in order to overcome service failures [18].

\section{Satisfaction}

Satisfaction is a person's feeling of happiness or disappointment that arises after comparing perceptions of the performance of a product or service with the perceived expectations [19]. Satisfied consumers certainly tend to convey positive things about the product concerned to other people and this is what the company expects [20]. Companies that adopt a customeroriented basis are more likely to provide quality, contribute to customer satisfaction and maintain organizational goals effectively and efficiently when compared to other competitors. Meanwhile, 
the measurement of customer satisfaction is by looking at evaluations and impressions from customers on the performance of products and services [21].

\section{Digital Wallets}

An electronic wallet or e-wallet is a means of electronic payment that can be used online through a mobile application [22]. Bank of Indonesia regulations regarding the implementation of financial technology, digital wallets are included in the payment gateway category. In Indonesia, the most popular e-wallet applications include Gojek (GoPay), LinkAja, OVO, and DANA. In 2018, Bank of Indonesia reported that e-wallet transactions reached almost IDR 21 trillion and is predicted to increase 17 times in 2023. The use of e-wallets allows easy non-cash transactions for its users, because they only need to use a smartphone that is used on a daily basis [23]. Digital wallets can be accessed by using a cell phone. Examples of companies that offer Mobile Money in Indonesia include e-toll from Mandiri Bank, OVO from Nobu Bank, T-CASH from the Telkomsel company, and so on.

\section{Millennial Generation}

Generation is a group of individuals who identify their group based on the similarity in birth year, age, location, and events in the life of that individual group that have a significant influence in the growth phase [24]. Millennials or generation Y were born in the period 1980-1994. The members of generation $Y$ today are certainly no longer teenagers, some are working and even have become parents. Generation $Y$ was born and grew when technological developments began to improve, during the $Y$ generation, many of the computer market had started to sell. Mobile phones began to be widely used in society, especially in the 2000s. Generation Y teenagers have started exchanging messages with short message services (SMS) and the trend of correspondence has been replaced by the trend of sending email.

\subsection{Research Framework and Hypotheses}

From the description above, the following research framework can be described:

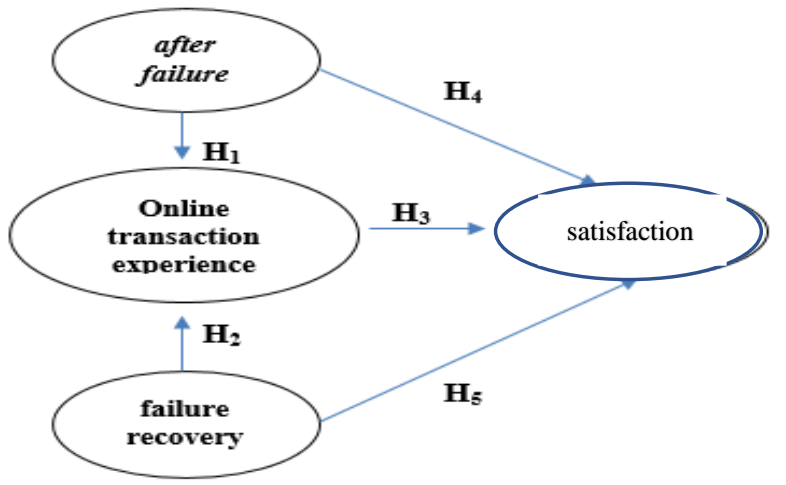

Figure 1. Research Framework

This study has the following hypothesis:

$\mathrm{H}_{1}$ : There is an effect after a transaction failure on the digital wallet user experience

$\mathrm{H}_{2}$ : There is an effect of transaction failure recovery on the user experience of digital wallets

$\mathrm{H}_{3}$ : There is an effect of the transaction experience on digital wallet user satisfaction

$\mathrm{H}_{4}$ : There is an effect after a transaction failure on digital wallet user satisfaction

$\mathrm{H}_{5}$ : There is an effect after a transaction failure on digital wallet user satisfaction

\section{Research Method}

The population of this research is all digital wallet users in the province of DKI Jakarta. Furthermore, sampling will be carried out, namely the number of samples = the number of questionnaires $\times 5$, because each question in the questionnaire is an unobserved variable, with the number of research questionnaires a total of 17 items, then 17 statements are observed. Thus, the required sample size is $5 \times 17=85$ respondents. However, to anticipate missing data and drop out questionnaires, $10 \%$ of the total sample was added (Hair et al., 2014). Therefore, 
the number of samples in this study is the number of samples = the number of questionnaires $\mathrm{x}$ $5+10 \%=17 \times 5+10 \%=94$ samples. Sampling using purposive sampling method, with the criteria of respondents: (1) Digital wallet users who have made transactions for at least 1 year, this is intended so that the respondent already has transaction experience, (2) At least 17 years old.

Quantitative methods will be used in this study, with after failure and failure as exogenous variables including online transaction experience and satisfaction as endogenous variables. Furthermore, the SEM analysis method will be used to see the effect between variables.

\section{Results and Analysis}

Based on the SEM method, the results of data processing by involving 100 respondents as samples, can be seen based on the suitability test of all models. Almost all tests show a good fit based on the suitability test analysis of all models from group 1 to group 7 including: Chi Square, ECVI, AIC and CAIC, Fit Index and Goodness of fit show good fit. RMSEA close fit and Critical N indicate marginal fit. From the analysis, it can be concluded that the suitability of all models still meets the requirements because of the 7 groups, 5 groups are still good fit. Furthermore, this research produces the following path diagram:

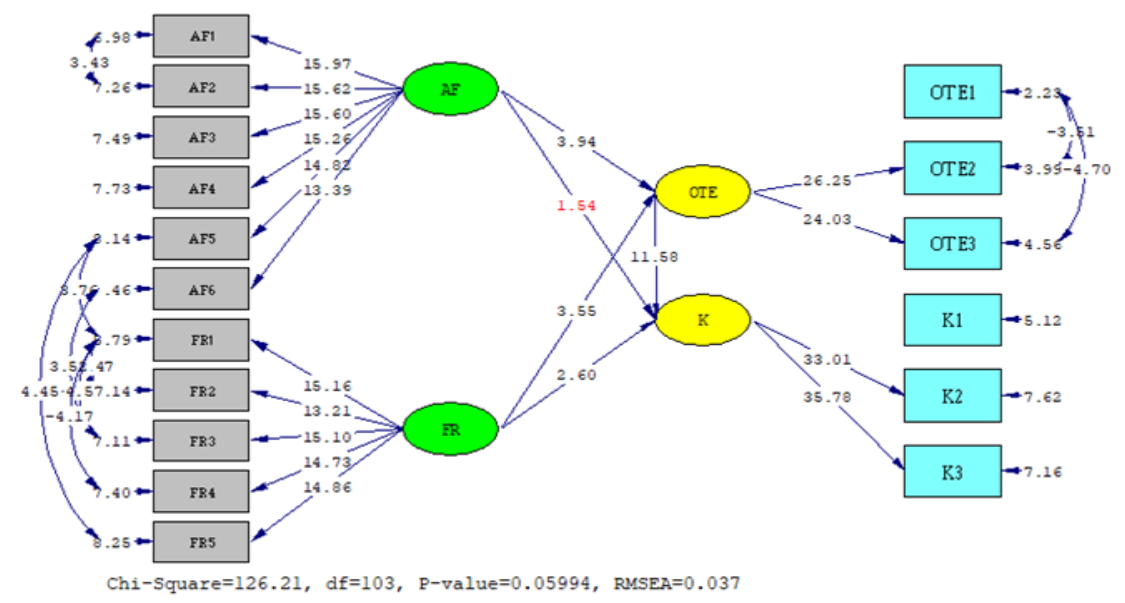

Figure 2. Path Diagram T-Value

Based on Figure 2 the T-Value Path Diagram, the hypotheses in this study are presented in the following table:

Table 1. Hypothesis Test for the Research Model

\begin{tabular}{|c|l|c|l|}
\hline Hipotesis & \multicolumn{1}{|c|}{ Hypothesis statement } & $\begin{array}{c}\text { T-Value } \\
(\mathbf{1}, 96)\end{array}$ & \multicolumn{1}{|c|}{ Information } \\
\hline $\mathrm{H}_{1}$ & $\begin{array}{l}\text { After failure effect on online transaction } \\
\text { experience digital wallet users }\end{array}$ & 3,94 & $\begin{array}{l}\text { The data support the } \\
\text { hypothesis }\end{array}$ \\
\hline $\mathrm{H}_{2}$ & $\begin{array}{l}\text { Failure recovery effect on online } \\
\text { transaction experience digital wallet } \\
\text { users }\end{array}$ & 3,55 & $\begin{array}{l}\text { The data support the } \\
\text { hypothesis }\end{array}$ \\
\hline $\mathrm{H}_{3}$ & $\begin{array}{l}\text { Online transaction ecperience affect the } \\
\text { satisfaction of digital wallet users }\end{array}$ & 11,58 & $\begin{array}{l}\text { The data support the } \\
\text { hypothesis }\end{array}$ \\
\hline $\mathrm{H}_{4}$ & $\begin{array}{l}\text { After failure has no effect on digital wallet } \\
\text { user satisfaction }\end{array}$ & 1,54 & $\begin{array}{l}\text { The data do not } \\
\text { support the } \\
\text { hypothesis }\end{array}$ \\
\hline $\mathrm{H}_{5}$ & $\begin{array}{l}\text { Failure recovery affect the satisfaction of } \\
\text { digital wallet users }\end{array}$ & 2,60 & $\begin{array}{l}\text { The data support the } \\
\text { hypothesis }\end{array}$ \\
\hline
\end{tabular}

Source: SEM Lisrel data processing results 


\subsection{Discussion}

The results of testing the first hypothesis $(\mathrm{H} 1)$ show after failure effect on online transaction experience digital wallet users. The digital wallet user experience includes the entire interaction between users and businesses, products or services from online transactions [25]. Through online transactions, service providers do not need to come face to face with digital wallet users, but interactions with digital wallet users can occur through online software such as websites, applications via mobile phones and so on. Here digital wallet users are directly involved in the cognitive and affective processes of the arrival of information from the digital wallet application, the ease of use of the digital wallet and whether or not the network system is smooth [26]. The age of respondents, namely the millennial generation, also affects the experience of digital wallet users, this generation is very dependent on technology, so that when they experience transaction failures, they can understand and also know what next steps should be taken to recover from these failures [27]. Then, the result that will be obtained by digital wallet users is an impression formation in the memory that will form a good or bad experience with the digital wallet application. Two psychological variables, cognition and affect, were consistently identified as important components of consumer behavior and customer experience [28]. Therefore, the quality of digital wallets in online software of products / services at digital wallet providers is very important to improve because it has an impact on the good / bad experience of digital wallet users transacting online.

The results of testing the second hypothesis $(\mathrm{H} 2)$ show failure recovery effect on online transaction experience digital wallet users. This means that the better the recovery of digital wallet failures, the better the customer experience in online transactions and vice versa. The results of this study support previous researchers, finding that there are different experiences after and before experiencing failure in online transactions [29]. Then when the company has taken recovery actions, this will create a different experience from the experience when a failure occurred. Failure recovery measures are efforts that every company must make to gain the trust back of its customers. It can be said that failure does not always have a negative effect, if recovery action is carried out quickly and appropriately it will have an effect on high satisfaction and have an indirect impact on promotion, in the form of word of mouth activities to the surrounding community.

The results of testing the third hypothesis $(\mathrm{H} 3)$ show online transaction experience affect the satisfaction of digital wallet users. The results of this study are appropriate, that the online transaction experience affects the satisfaction of independent transaction services. [30]. Digital wallet application makers have to think about hundreds or even thousands of possibilities that will happen when users perform self-service activities. The factors of convenience, speed and accuracy of service when making online transactions need to be considered, to minimize failures for digital wallet users. If digital wallet users feel that they always have problems with every transaction with a digital wallet, it can create a negative impression on the products and services of the digital wallet. Currently the use of digital wallets is the main choice for most people, because online transactions with digital wallets are very easy and efficient, can be done anywhere and anytime, making it easier for digital wallet users to meet their needs.

The results of testing the fourth hypothesis $(\mathrm{H} 4)$ show after failure has no effect on digital wallet user satisfaction. This contradicts the theory and previous studies. According to researchers, these findings contradict the theory due to two things, the first is the influence of the respondent's gender. When viewed from the majority of user respondents are women as much as $60 \%$. This is related to the use of the digital wallet itself. Application-based research institutes such as Snapcart, conducting research on consumer behavior in transacting with digital payment applications show that the majority for retail transactions are $28 \%$. Women have a tendency to like shopping, this opinion is supported by research that, there is a big difference between men and women in terms of their responses to shopping, where if some men do not like shopping, most women say they like the shopping experience, and although most women feel shopping is a fun thing, most men don't have the same response. Furthermore, women tend not to really like things that smell of technology. The Commission on the Status of Women and 20 years of Beijing Platform for Action recommending the government and stakeholders to advocate for the low level of women and girls in ICT (Information Communication and Technology) and STI (science, technology and innovation). So that when they experience failure in transacting with digital wallets, they can accept it as a learning process and are willing to remain as users. There is a

The Effect of Transaction Experience Using Digital Wallets on User Satisfaction in Millennial Generation (Suryari Purnama) 
different effect of service failure on online customers and offline customers, where online customers tend to blame themselves so that they expect less service failure recovery services when compared to offline customers. In addition, the benefits that are felt are far greater than the failures that are experienced, especially when recovery from failures is carried out quickly and precisely. The technological advancement of this payment instrument is very beneficial for the community. With the presence of a digital wallet, it provides convenience and security in shopping and other payments. Customers don't have to bother carrying cash, just use the help of a cellphone or computer so customers can get the desired item.

The results of the liman hypothesis testing (H5) show failure recovery affect the satisfaction of digital wallet users. Failures that may occur in the use of digital wallets are incorrectly entering the nominal money when transferring, or wrong account number when transferring, which most often is entering the wrong amount when topping up, the amount transferred is mostly one zero, or it can even be reduced to one zero. However, this can be reported to the digital wallet customer service provider and will be responded to as soon as possible. Speed in responding to customer complaints is a must for digital wallet providers because of the high competition among providers [31]. In addition, the needs and benefits obtained due to the use of this digital wallet are quite satisfying to users rather than a perceived failure [32]. Especially in this cashless era and it is also effective and efficient by using a digital wallet. So that recovery after failure greatly affects the increase in digital wallet user satisfaction [33].

\section{Conclusion}

Based on the problems and objectives proposed in this study, the results of this study can be concluded: When viewed from the largest number of respondents based on gender, $60 \%$ were women, 65\% respondents' age ranged from 18-40 years, with 64\% unmarried status and the number of monthly transactions above 1 million is $46 \%$. When viewed based on income, the largest digital wallet users, namely $63 \%$, earn between Rp. 4 million - Rp. 6 million. This research also shows that the most famous and desirable brands are OVO (35.5\%), GoPay (29.6\%) and finally DANA with $20.1 \%$.

Meanwhile, the conclusions based on the results of the questionnaire data processing are: (1) After failure has an effect on the online transaction experience of digital wallet users; (2) Failure recovery has an impact on the online transaction experience of digital wallet users; (3) Online transaction experience has an influence on digital wallet user satisfaction; (4) After failure has no effect on digital wallet user satisfaction; (5) Failure recovery has an effect on digital wallet user satisfaction.

\section{References}

[1] A. Alwiyah, C. Greisy, and A. Afitri, "Implementation Of Information Systems On Ecommerce Websites As Media To Deliver Information," Aptisi Trans. Technopreneursh., vol. 1, no. 2, pp. 127-133, 2019.

[2] M. Mardiana, N. Lutfiani, and R. S. Saga, "The Online Sales Application Of Black And White Print Based On Yii Framework On Higher Education E-Commerce Website," Aptisi Trans. Technopreneursh., vol. 1, no. 2, pp. 118-127, 2019.

[3] U. Rahardja, P. A. Sunarya, Q. Aini, and S. R. Dewi, "Solusi Payment Online Berbasis Cloud Accounting Pada Manajemen Perguruan Tinggi," InfoTekJar J. Nas. Inform. dan Teknol. Jar., vol. 3, no. 2, pp. 9-15, 2019.

[4] G. W. Mugo and M. Mathu, "Assessment of Customer Service Provision for Enhanced User Satisfaction in Academic Libraries: A Case Study of St Paul's University Library, Kiambu County, Kenya," Int. J. Curr. Asp., vol. 5, no. 1, pp. 20-34, 2021.

[5] A. Gupta, R. K. Singh, and S. K. Mangla, "Evaluation of logistics providers for sustainable service quality: Analytics based decision making framework," Ann. Oper. Res., pp. 1-48, 2021.

[6] E. Tjahjaningsih, S. Widyasari, A. Maskur, and L. Kusuma, "The Effect of Customer Experience and Service Quality on Satisfaction in Increasing Loyalty," in 3rd International Conference of Banking, Accounting, Management and Economics (ICOBAME 2020), 2021, pp. 395-399.

[7] A. Byram, "A STUDY ON CUSTOMER PERCEPTION AND ATTITUDE TOWARDS 3D VIRTUAL REALITY SHOPPING,” Inf. Technol. Ind., vol. 9, no. 1, pp. 1329-1342, 2021. 
[8] U. Rahardja, N. Lutfiani, and S. Amelia, "Creative Content Marketing In Scientific Publication Management In Industrial Era 4.0," Aptisi Trans. Manag., vol. 3, no. 2, pp. 168178, 2019.

[9] M. Anshari, M. A. Arine, N. Nurhidayah, H. Aziyah, and M. H. A. Salleh, "Factors influencing individual in adopting eWallet," J. Financ. Serv. Mark., vol. 26, no. 1, pp. 1023, 2021.

[10] P. Limo, A. Kimwolo, and Z. Mohammed, "Does Relationship Quality Affect Customer Satisfaction when Service Failure Occurs? Evidence from Customers of Commercial Banks in Eldoret Town, Kenya," African J. Educ. Sci. Technol., vol. 6, no. 2, pp. 40-52, 2021.

[11] C. Zhang, J. Park, M. A. Bonn, and M. Cho, "Understanding Customer Responses to Service Failures during the COVID-19 Pandemic for Sustained Restaurant Businesses: Focusing on Guanxi," Sustainability, vol. 13, no. 6, p. 3581, 2021.

[12] A. Kumar, A. Adlakaha, and K. Mukherjee, "The effect of perceived security and grievance redressal on continuance intention to use M-wallets in a developing country," Int. J. Bank Mark., 2018.

[13] C. Flavián, S. Ibáñez-Sánchez, and C. Orús, "The impact of virtual, augmented and mixed reality technologies on the customer experience," J. Bus. Res., vol. 100, pp. 547-560, 2019.

[14] X. Luo, S. Tong, Z. Lin, and C. Zhang, "The Impact of Platform Protection Insurance on Buyers and Sellers in the Sharing Economy: A Natural Experiment," J. Mark., vol. 85, no. 2, pp. 50-69, 2021.

[15] A. J. Baliga, V. Chawla, V. Sunder M, and R. Kumar, "Barriers to service recovery in B2B markets: a TISM approach in the context of IT-based services," J. Bus. Ind. Mark., 2021.

[16] D. Yagil, "Abuse from organizational outsiders: Customer aggression and incivility," Spec. Top. Part. Occup. Prof. Sect., pp. 109-134, 2021.

[17] U. Kustiawan, "Pengaruh Kualitas Teknologi Jasa Layanan Mandiri Setelah Terjadi Kegagalan dan Pemulihan Kegagalan Teknologi Jasa Layanan Mandiri Terhadap Pengalaman Pelanggan, Kepuasan Pelanggan, dan Intensi Untuk Membeli Kembali Pada Website Belanja Online= The Effect ," 2018.

[18] Y. Al Mousa, P. Callaghan, M. Michail, and G. Caswell, "Saudi service users' perceptions and experiences of the quality of their mental health care provision in the Kingdom of Saudi Arabia (KSA): A qualitative inquiry," Int. J. Ment. Health Nurs., vol. 30, no. 1, pp. 300-316, 2021.

[19] F. Hussein and H. Hartelina, "After Sales Service For Smartphone Iphone To Customer Loyalty," Aptisi Trans. Manag., vol. 5, no. 1, pp. 62-72, 2021.

[20] E. Depiana and H. Hartelina, "Marketing Service on Customer Satisfaction of Yamaha Motorcycles at PT Ramarayo Perdana Karawang," Aptisi Trans. Manag., vol. 5, no. 1, pp. 11-19, 2021.

[21] A. Dandis, L. T. Wright, D. M. Wallace-Williams, I. Mukattash, M. Al Haj Eid, and H. Cai, "Enhancing consumers' self-reported loyalty intentions in Islamic Banks: The relationship between service quality and the mediating role of customer satisfaction," Cogent Bus. Manag., vol. 8, no. 1, p. 1892256, 2021.

[22] S. Teng and K. W. Khong, "Examining Actual Consumer Usage of E-wallet: A Case Study of Big Data Analytics," Comput. Human Behav., p. 106778, 2021.

[23] S. Kesharwani, "Unit-5 E-Payment," Indira Gandhi National Open University, New Delhi, 2021.

[24] C. Germain and C. Knight, "8 Helping Individuals, Families, and Groups with Stressful Life Transitions and Traumatic Events," in The life model of social work practice, Columbia University Press, 2021, pp. 258-309.

[25] N. Lutfiani, U. Rahardja, and I. S. P. Manik, "Peran Inkubator Bisnis dalam Membangun Startup pada Perguruan Tinggi," J. Penelitan Ekon. dan Bisnis, vol. 5, no. 1, pp. 77-89, 2020.

[26] S. Gupta and D. Ramachandran, "Emerging Market Retail: Transitioning from a ProductCentric to a Customer-Centric Approach," J. Retail., 2021.

[27] J. E. Collier, M. Breazeale, and A. White, "Giving back the 'self' in self service: customer preferences in self-service failure recovery," J. Serv. Mark., 2017. 
[28] S.-Y. Tzeng, M. Ertz, M.-S. Jo, and E. Sarigöllü, "Factors affecting customer satisfaction on online shopping holiday," Mark. Intell. Plan., 2021.

[29] E. Stiawan, "PENGARUH KEGAGALAN DAN PEMULIHAN SELF SERVICE TECHNOLOGY TERHADAP ONLINE SHOPPING EXPERIENCE, SATISFACTION DAN REPURCHASE INTENTION: SEBUAH TINJAUAN DALAM PERSPEKTIF CRITICAL SDL," J. BAABU AL-ILMI Ekon. dan Perbank. Syariah, vol. 1, no. 2, 2018.

[30] S. I. S. Al-Hawary and W. F. Al-Smeran, "Impact of electronic service quality on customers satisfaction of Islamic banks in Jordan," Int. J. Acad. Res. Accounting, Financ. Manag. Sci., vol. 7, no. 1, pp. 170-188, 2016.

[31] F. Li, H. Lu, M. Hou, K. Cui, and M. Darbandi, "Customer satisfaction with bank services: The role of cloud services, security, e-learning and service quality," Technol. Soc., vol. 64, p. 101487, 2021.

[32] Y.-W. Chang and J. Chen, "What motivates customers to shop in smart shops? The impacts of smart technology and technology readiness," J. Retail. Consum. Serv., vol. 58, p. 102325, 2021.

[33] F. Z. A. Razak, A. E. Mohktar, A. A. Rahman, and M. Z. Z. Abidin, "Influence of trust in information system: Understanding user's satisfaction of e-campus usage," in Journal of Physics: Conference Series, 2021, vol. 1793, no. 1, p. 12015. 